\title{
Is COVID-19 a proteiform disease inducing also molecular mimicry phenomena?
}

\section{Francesco Cappello ${ }^{1}$}

Accepted: 15 April 2020 / Published online: 20 April 2020

(C) Cell Stress Society International 2020

It is evident that COVID-19, the disease due to severe acute respiratory syndrome coronavirus 2 (commonly abbreviated SARS-CoV-2) etiological agent, is not uniquely a respiratory disease, at least in a subset of patients. It is possible that we are facing a "proteiform" disease (from Proteus, the sea god who could change shape to avoid capture). As other coronavirusinduced infections, it initially affects the upper airways, but can move abruptly to the lower respiratory tract. Lastly, while physicians treat the bilateral lung pneumonia of their patients, systemic complications can appear characterized by thrombosis, disseminated intravascular coagulation and multi-organ failure.

Health systems worldwide are now facing three major problems: 1) to identify asymptomatic carriers of infection; 2) to give effective home care to symptomatic people; 3 ) to properly stage hospitalized patients to avoid overwhelming numbers in intensive care units. This last group of patients experience, among other clinical signs, very low $\mathrm{pO}_{2}$ blood concentrations due to the destruction of lung parenchyma and massive activation of both innate and acquired immune responses.

Presently, only ex juvantibus treatments are done in the most severe cases, since we are far from understanding what primes the systemic vascular complications. The term ex juvantibus or sometimes "ex adiuvantibus" from Latin, meaning "from that which helps" refers, in medical contexts, to the process of making an inference about disease causation from an observed response. I have a modest proposal that I would like to share with our readers.

After studying the published clinical reports, what surprised me is that most patients who had the most severe complications were affected by two comorbidities (or their longterm effects): hypertension and diabetes. Both of them induce,

Francesco Cappello

francesco.cappello@unipa.it

1 University of Palermo, Palermo, Italy among other problems, chronic stress on endothelial cells that in turn can express molecules on their plasma membranes abnormally as an effect of post-translational modifications of intracellular proteins, including some heat shock proteins. This condition can predispose cells and tissues to molecular mimicry phenomena that may occur during an infection (Cappello et al. 2009; Delunardo et al. 2013; Kotlarz et al. 2013; Mayr et al. 1999; Sun et al. 2006).

If we add to this chronic stress an acute stress due to the low $\mathrm{pO}_{2}$ blood concentration and systemic inflammation, all the conditions for a perfect storm are present. My hypothesis is that the disease escapes from the hands of the doctors who are treating it through a fog of molecular mimicry phenomena: antibodies against the viruses might cross-react with epitopes of self-proteins abnormally expressed on the plasma membrane surface of stressed endothelial cells. In turn, these autoimmune reactions against endothelium can generate thrombosis, disseminated intravascular coagulation and multi-organ failure.

Surprisingly, to date, no items appear on PubMed or other biomedical search engines if we look for "molecular mimicry" and "COVID-19". Hence, I would like to strongly encourage researchers and physicians to consider this conjecture among others. In vitro and in vivo studies along with bioinformatic analyses can be used to evaluate this hypothesis.

\section{References}

Cappello F, Conway de Macario E, Di Felice V, Zummo G, AJL M (2009) Chlamydia trachomatis infection and anti-Hsp60 immunity: the two sides of the coin. PLoS Pathog 5(8):e1000552. https://doi. org/10.1371/journal.ppat.1000552

Delunardo F, Scalzi V, Capozzi A, Camerini S, Misasi R, Pierdominici M, Pendolino M, Crescenzi M, Sorice M, Valesini G, Ortona E, Alessandri C (2013) Streptococcal-vimentin cross-reactive antibodies induce microvascular cardiac endothelial proinflammatory phenotype in rheumatic heart disease. Clin Exp Immunol 173(3):419 429. https://doi.org/10.1111/cei.12135 
Kotlarz A, Tukaj S, Krzewski K, Brycka E, Lipinska B (2013) Human Hsp40 proteins, DNAJA1 and DNAJA2, as potential targets of the immune response triggered by bacterial DnaJ in rheumatoid arthritis. Cell Stress Chaperones 18(5):653-659. https://doi.org/10.1007/ s12192-013-0407-1

Mayr M, Metzler B, Kiechl S, Willeit J, Schett G, Xu Q, Wick G (1999) Endothelial cytotoxicity mediated by serum antibodies to heat shock proteins of Escherichia coli and chlamydia pneumoniae: immune reactions to heat shock proteins as a possible link between infection and atherosclerosis. Circulation. 99(12):1560-1566

Sun X, Welsh MJ, Benndorf R (2006) Conformational changes resulting from pseudophosphorylation of mammalian small heat shock proteins-a two-hybrid study. Cell Stress Chaperones 11(1):61-70

Publisher's note Springer Nature remains neutral with regard to jurisdictional claims in published maps and institutional affiliations. 